\title{
The economic policy cycle and public debt in México. A retrospective analysis of 2012-2016 period
}

\section{El ciclo de política económica y la deuda pública en México. Un análisis retrospectivo del período 2012-2016}

\author{
PÉREZ-CRUZ, Omar Alejandro*ł, NANDE-VÁZQUEZ, Edgard Alfredo and MARTÍNEZ- \\ VERDUGO, Juan Carlos
}

ID $1^{\text {st }}$ Author: Omar Alejandro, Pérez-Cruz / ORC ID: 0000-0003-3367-8259

ID $1{ }^{\text {st }}$ Coauthor: Edgard Alfredo, Nande-Vázquez / ORC ID: 0000-0001-6029-2242

ID $2^{\text {nd }}$ Coauthor: Juan Carlos, Martínez-Verdugo / ORC ID: 0000-0003-2181-1868

DOI: $10.35429 / J S R .2020 .17 .6 .22 .31$

Received January 10, 2020; Accepted April 01, 2020

\begin{abstract}
The objective of this research is to measure the effects of intellectual capital (human, organizational and technological) on financial performance. The data belong to the economic censuses of the years 2009 and 2014 in the field of tourism, with information on hotel activities in the 32 states of the Mexican Republic. The least squares methodology was applied with adjusted panel-type errors, analyzing the human, organizational and technological influence on financial performance. The results suggest that in the first place there is the technological dimension, as it is significant in its two indicators in relation to financial performance. Second, there is the human, with two of two significant indicators. Finally, the organizational one, with one of three significant indicators in relation to the dependent variable. According to the hypotheses, technological capitals and the human capital establish a significant and positive effect with financial performance. However, intellectual capital, jointly, does strengthen finances. This work contributes, with empirical evidence, to establishing links between the different types of intangibles and financial performance, as well as helping to understand the drivers of financial performance and therefore a sustainable competitive advantage.
\end{abstract}

\begin{abstract}
Resumen
El endeudamiento componente del gasto público estatal en México, se encuadra en el ciclo político presupuestal (CPP) como parte de la teoría general del ciclo político económico (CEP). El objetivo de esta investigación fue analizar de manera retrospectiva, los determinantes del endeudamiento público de las entidades federativas de México en el periodo de 2012-2016. Lo cual permitirá conocer a los gobiernos de los diferentes estados, conocer las variables económicas que inciden en las decisiones electorales y mantener el poder. Las variables utilizadas fueron relativas a la información presupuestaria: gasto en inversión, gasto de inversión presupuestaria, transferencias de capital, producto interior bruto per cápita, autonomía financiera, ahorro bruto per cápita, demografía poblacional y año electoral. Para lo cual, se estimaron modelos autorregresivos extendidos que incorporan variables (dicótomas) electorales y se controlan mediante los efectos del ciclo económico. Los resultados muestran la presencia del CEP en el gasto público estatal, en el rubro de los gastos de capital, lo que permite explicar que el endeudamiento es un recurso que financia obra pública en los estados de México.
\end{abstract}

Gasto público, Deuda pública, Ciclo político económico, Datos panel 


\section{Introduction}

Financial performance is a key indicator of business performance, and one of the strategies to generate a competitive advantage (Manju, Kashiramka, \& Jain, 2018). In this context, knowledge is an even more critical element than traditional resources such as tangible assets, to achieve sustainable competitive advantage (Amiri, Shirkavand, Chalak, \& Rezaeei, 2017). Intellectual capital (CI) integrates the intangible assets of companies, helping them compare their performance and the achievement of sustainable success (Dinh, Kang, Morris, \& Schultze, 2018). This research considers three aspects of intellectual capital: human, organizational and technological, each with its own characteristics (Papageorgiadis, Xu, \& Alexiou, 2019). For example, human capital refers to company personnel, who apply the knowledge, skills and abilities to develop work activities (Antoni, Maug, \& Obernberger, 2019). Organizational capital refers to experience and tacit knowledge in the organization; It is presented in the form of manuals of procedures, processes, structures and databases with information about the company's operations (Sun \& Xiolan, 2019). For its part, technological capital explains the degree of systematization of processes in the organization; it is expressed in the form of a PC, office equipment and other peripheral elements for the company's operations (Badinger, Egger, \& von Ehrlich, 2019).

Although intellectual capital has been labeled as one of the factors that drive the success and competitiveness of the company, the existing literature has not been able to differentiate the direct influence between each of the different elements of intellectual capital in financial performance. (Sharabati, Nour, Shamari, Durra, \& Moghrabi, 2016). According to $\mathrm{Xu} \& \mathrm{Li}$ (2019) the impact of intellectual capital on financial performance is a widely accepted relationship, however, there is still a need to expand the empirical evidence of this impact. For example, research on financial performance management has been oriented to different sizes (small and medium versus large companies), sectors (high technology versus low technology) and sources (income vs. indebtedness).

Each size, sector or source, has different contexts, and each of these studies leads to different results.
Thus, research on financial performance has not been consistent in the results regarding the impact of each component of intellectual capital (Shou, Prester, \& Li, 2018). To expand the consistency of the results, Garanina \& Dumay (2018) indicate that new research should be carried out that measures the impact of each element of intellectual capital, individually, on its contribution to financial performance.

Performance, however, financial performance has different results for the organization. For example, performance can lead to raising the quality of its products, expanding the company's activities or improving its competitiveness. So that the analysis of financial performance helps companies to reduce performance deficiencies and explore new market opportunities. This is critical for the separate understanding of the different elements of intellectual capital and its impact on financial performance. In this sense, Ginesti, Caldarelli \& Zampella (2018) point out that this is critical for the following reasons: first, because it is necessary to know the different effects that the elements of intellectual capital cause in financial performance. Second, because financial performance strengthens sustainable competitive advantage; therefore, a better understanding is obtained on how companies capitalize and obtain sustainable competitive advantages. Therefore, this research analyzes separately the impact that each of the elements of intellectual capital has on the financial performance of companies in the tourism sector in Mexico.

\section{Literature Review}

\section{Human capital}

Of the elements that integrate intellectual capital, human capital is the most important because of its reference to the capitalization of the organization's knowledge. By integrating the skills, abilities and skills of its staff, it is essential to perform the other activities of the company (Overstreet, Skipper, Huscroft, Cherry, \& Cooper, 2019). This capital includes management skills and entrepreneurial experiences, knowledge, academic levels, academic achievements, training, training, individual experience, age, as well as the household income related to the company (Badinger, Egger, \& von Ehrlich, 2019). 
The existing literature on human capital establishes different characteristics about it, all in accordance with the specific human capital of the person, and the specific human capital of the company, which can traditionally refer to the enrichment of knowledge and skills that are highly valued in a specific sector.

For example, in the case of the specific human capital of the person, some research has shown a positive association between the entrepreneur's human capital and the knowledge related to the company and its level of success (Ma, Zhu, Meng, \& Teng, 2019). Regarding the specific human capital of the company, this is the result of years of work, building specific skills and abilities learned by the work done in a particular company or business sector, and is applicable to a wide range of companies and industries. Thus, the efficient use of these skills and abilities of the staff, results in the generation of competitive advantages (Liu, Chang, \& Fang, 2019).

Different investigations have identified the association between the specific human capital of the company and its economic growth (Pelinescu, 2015). It is also suggested that this capital becomes more important for industrial innovation when the main actors in that industry are inclined to exchange knowledge (Buenechea-Elberdin, Sáenz, \& Kianto, 2018). This specific knowledge of the business sector is often of a tangible nature, therefore it is easy to identify for the specialists in the sector.

Therefore, this research focuses on the specific human capital of the company, which focuses on the individual knowledge, skills and abilities that are carried out in it. This capital is traceable to a specific spectrum of companies and industrial sectors (Osei, Agyapong, \& Owusu Kwateng, 2019). According to Felli \& Harris (2018), the distinctive indicators of this entrepreneurial human capital are the creativity, intelligence and skills of employees, all of whom have developed as a product of their experience in certain positions and functions throughout Your career This capital contributes to the generation of new ideas and knowledge in their organizations and, consequently, to the generation of profits.
In this way, our work maintains that the specific human capital of the company enables the generation of income, since the most skilled and experienced employees are better prepared to face challenges and solve problems, which leads to developing sustainable competitive advantages (Osei, Agyapong, \& Owusu Kwateng, 2019). Finally, here the specific human capital of the company is understood as those workers with specialized knowledge in the tourism sector, which allows them to capture knowledge, skills and abilities of the tourism industry to generate greater profits.

\section{Organizational capital}

Stucki \& Wochner (2018) define organizational capital as the sum of repeated activities and behaviors in an organizational context. These activities are not entirely tangible, they also include intangibles that are created, codified and preserved per se. According to Kmieciak (2019) these activities are preserved in the form of procedural manuals, financial statements, organizational structures, databases, among other documents. In such a way, that anyone who has permission or interest in acquiring knowledge of the company can access this information. This organizational report contains historical information about the organization, which guarantees the availability of knowledge for proper decision making (Stucki \& Wochner, 2018).

The organizational capital is maintained in the structures and processes of an organization, which strives to preserve, use and retrieve the information of the company, for which these entities need specific knowledge, skills and abilities to be able to integrate and generate the utilities (Lee, Kim, \& Joshi, 2017). Werr \& Runsten (2013) point out that, in order for this knowledge integration process to take place, it is necessary to store information and daily experiences, so that they are part of the daily reports of the organizational processes. By socializing all this collective knowledge, it becomes clear that the mistakes that have been incurred before, will no longer be repeated, and managers will be in more favorable conditions to capitalize on this knowledge. 
When organizational capital is conceived as an organizational memory, it is more understandable to use this capital as another resource to mobilize knowledge in the organization, which persists even when people no longer collaborate in the organization. Thus, in this work organizational capital is understood as the set of tangible elements such as machinery, real estate and transport equipment; as well as the intangibles involved in repeated activities and behaviors in an organizational context.

\section{Technological capital}

It is commonly based on the idea that organizations have limited resources from which they establish their competition strategies, while the missing resources are acquired from external, subcontracted and technology transfer providers. However, with the simple acquisition of technology one falls into a unilateral process, where the knowledge generated by this commercial relationship is wasted. When requesting a specific service or product, the supplier acquires in tangible or intangible forms, knowledge and learning, which constitutes a transfer of technological capital (Kum-Sik \& Anchor, 2017).

Thus, recent literature demonstrates that commercial exchange is one of the transfer paths for knowledge and technology. This transfer between countries represents an advantage for the more developed economies, since having greater economic capital, they have the capacity to acquire better technology and, consequently, to progress technologically. In this way, the acquisition of knowledge is exemplified with a wide range of materials, devices, peripherals and equipment that induce technological progress through the improvement of productive efficiency (Villasalero, 2014). In this regard, Wang, Su, Wang \& Zou (2019) and Tovar \& Tavares (2015), show that by incorporating the best quality technological products in the productive systems of the host country, they impact on one of the indicators of productive efficiency at the level country, which is the total factor productivity (TFP).

It is through the transmission of technology from the most advanced countries that trade occurs between nations and increases growth in less developed countries (Garechana, Rio-Belver, Zarrabeitia, \& Alvarez-Meaza, 2019).
However, according to Hye-Young (2018), these collateral benefits on the development of the recipient country are subject to their technological absorption capacity (Benini, 2016). In turn, this technological absorption capacity is related to the formation of specialized human capital of the recipient country (Jung \& López-Baso, 2017).

When considering transfer as another element of technological capital, Wood, Coe \& Wrigley (2016) highlight the role of multinationals in generating new knowledge for retail companies, which generate adaptable and multiscale strategies to respond to differences of national markets. In their research, the authors generate evidence of the influence exerted by foreign direct investment on the transfer of technological capital and the expansion of trade.

Thus, in this work, technological capital is understood as the set of office equipment (personal computers and desks; telephones, copiers, scanners, among others) and peripheral components (accessories and performance improvement equipment), involved in the activities in a technological context.

\section{Financial performance}

All private companies arise to generate economic value (Kum-Sik \& Anchor, 2017). These companies are characterized by limitations in their resources and by making decisions for the allocation of these resources cautiously. Having sufficient resources (especially financial resources) is vital for companies, since the application of these resources must be maximized for operations and the achievement of the organization's objectives (Kogan, Papanikolaou, Seru, \& Stoffman, 2017). However, empirical evidence on financial performance in hotel organizations is scarce.

Financial performance is a key indicator for the success of an organization, since its proper management is essential for the financial health of the company and for maintaining the competitive advantage in the market (Prawitz \& Cohart, 2016). However, the current literature shows dispersed, inconsistent results that are generalized by particularities of size or productive sector (Sardo \& Serrasqueiro, 2018).

PÉREZ-CRUZ, Omar Alejandro, NANDE-VÁZQUEZ, Edgard Alfredo and MARTÍNEZ-VERDUGO, Juan Carlos. The economic policy cycle and public debt in México. A retrospective analysis of 2012-2016 period. Journal of Social Researches. 2020 
Thus, some authors suggest that financial performance is positively associated with intellectual capital, because finances mitigate the ups and downs of the market and strengthen competitive advantage ( $\mathrm{Xu} \& \mathrm{Li}, 2019)$ and (Sardo \& Serrasqueiro, 2018). On the other hand, other authors explain that financial performance maintains a moderating effect with operating costs and with the increase and decrease of sales in the medium and long term, which makes it difficult to adjust intellectual capital to maintain adaptation to the challenges posed by the market (Argilés-Bosch, GarcíaBlandón, Ravenda, Valencia-Silva, \& Somoza, 2017). Thus, the inconsistency and dispersion of the results demand greater empirical evidence to show the internal relations between the mediating effects of intellectual capital and financial performance (Carnes, Xu, Sirmon \& Karadag, 2019).

That is why the following hypotheses were established:

H1: Intellectual capital has a significant and positive effect on financial performance.

As explained above, the IC includes three components: technological capital, human capital and organizational capital. Because there can be different significant effects on each of the three components of the IC, it was interesting to analyze the effect of each of these elements separately. Such an analysis would increase the power of explanation of the conceptual framework. Therefore, the following hypotheses were raised:

H2: Human capital has a significant and positive effect on financial performance.

H3: Organizational capital has a significant and positive effect on financial performance.

H4: Technological capital has a significant and positive effect on financial performance.

\section{Methodology}

To test the hypotheses raised in this work, this research gathered information about the companies involved in the hotel industry in Mexico.
The information was obtained from the 2009 and 2014 economic censuses of the National Institute of Geography and Statistics (INEGI); This of the tourism sector, with information on hotel activities in the 32 states of the Mexican Republic.

The continuous growth of this sector in Mexico and its high competition drive this economic sector to seek financial efficiency. Thus, hotel companies tend to develop new strategies to seek a sustainable competitive advantage. These strategies arise from the application of existing knowledge in the industry, and on other occasions, they are completely new strategies in the market.

The data analysis of the relationship between intellectual capital and financial performance was carried out incorporating data from more than 300 thousand establishments dedicated to hotels. This sector, like others in the Mexican economy, is made up of $80 \%$ of small and medium-sized companies (SMEs) of the existing hotel offer in Mexico (Benítez, 2016). Thus, the research analysis units were SMEs that actively participate in the hotel industry and have at least constant returns on activities in this sector. This methodological strategy is consistent with other studies such as those of Pérez and Barragán (2018), and those of Rivera, Rivera and Reducindo (2016).

\section{Measurements}

Intellectual capital: human, organizational and technological.

The independent variable of intellectual capital is composed of three factors: human, organizational and technological capital. This research integrates these three factors of the intellectual capital of labor by Sardo \& Serrasqueiro (2018). Human capital was measured by the number of administrative employees and the total number of staff employed in the hotels. These indicators reflect the amount of staff that the hotel sector has as a potential value of the organization's skills and knowledge. Organizational capital was measured through machinery and production equipment, real estate and transportation equipment units. Finally, technological capital includes office equipment and peripheral components. 
Estimation model.

As a first step for the estimation of the econometric model, the presence of endogeneity was identified, for which the panel data methodology was applied, because the information analyzed was obtained transversally (in the 32 states of Mexico), as well as longitudinal (from 2009 and 2014).

In this way, the estimates are more reliable by having more observations, as well as a longer period of time.

For this purpose, the fixed effects (EF) and random effects (EA) models were applied to model the individual character of each state in the country. In this way, the applied model identifies financial performance as a strategic factor in the concept of intellectual capital, in addition to being correlated with the competitiveness of companies in the identified states. As independent variables, human capital (administrative employees and employed personnel of the hotel sector) were specified; organizational capital (machinery, real estate and transport equipment) and technological capital (office equipment and peripheral components). Thus, the linear equation of the model was as follows:

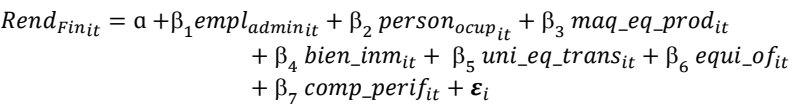

for $\mathrm{i}=1, \ldots, 2$ and $\mathrm{t}=2009, \ldots, 2014$ for

Given the above, the standard error estimates corrected for panel (EECP) were applied.

\section{Results}

The first hypothesis seeks to estimate the influence of human capital on financial performance. Table 1 shows the significance of the relationships found.

\begin{tabular}{|l|r|r|}
\hline \multicolumn{1}{|c|}{ Dependent variable EEPC Model } \\
\hline Financial Performance & Coefficient & $\begin{array}{l}\text { Standard } \\
\text { Error }\end{array}$ \\
\hline Busy staff and & $1.65171 *$ & .4537879 \\
\hline $\begin{array}{l}\text { Machinery } \\
\text { production equipment }\end{array}$ & 1.09 & 1.80 \\
\hline Constant & 0.9627 & \\
\hline R- square & $637042 *$ & 119.0669 \\
\hline Observations & 0.0000 & \\
\hline Chi-square & $* *$ significant at 5\%; *** \\
\hline $\begin{array}{l}\text { Note: * significant at 1\%; } \\
\text { significant at 10\%. }\end{array}$
\end{tabular}

Table 1 EEPC model of human capital and financial performance

Source: self made

From the previous table it can be seen that only human capital (employed personnel) and organizational capital (machinery and production equipment), maintain a significant and positive relationship in relation to the dependent. This partially complies with hypothesis 1 , which sought to estimate the effect of IC on financial performance.

To perform a more robust analysis, we also sought to estimate the individual impact of the factors of intellectual capital on financial performance, so each factor was analyzed separately. All estimates were made with financial performance as a dependent variable. The first element estimate was that of human capital, and the results are shown in Table 2.

\begin{tabular}{|l|r|r|}
\hline \multicolumn{1}{|c}{ Dependent variable } & \multicolumn{2}{c|}{ EEPC Model } \\
\hline Financial Performance & Coefficient & $\begin{array}{l}\text { Standard } \\
\text { Error }\end{array}$ \\
\hline Busy staff & $5377.597 *$ & 532.9904 \\
\hline $\begin{array}{l}\text { Administrative } \\
\text { employees }\end{array}$ & $121.6726 * * *$ & 75.7777 \\
\hline Constant & 1.09 & 1.80 \\
\hline R- square & 0.9433 & \\
\hline Observations & 64 & \\
\hline Chi-square & 0.0000 & \\
\hline $\begin{array}{l}\text { Note: } * \text { significant at 1\%; } \\
\text { significant at } 10 \% .\end{array}$ & significant at 5\%; *** \\
\hline
\end{tabular}

Table 2 EEPC model of intelectual capital and financial performance

Source: self made

The results show that the significant and positive trend variable was that of administrative employees. The employed staff found themselves at the $10 \%$ limit, also with a positive trend. 
This explains that not only the staff that integrates the economic units of the hotel sector contributes to financial performance, but, the ones that contribute the most are the staff with administrative functions. This is due to the fact that the control of the resources exercised by administrative employees allows greater efficiency in financial performance. With this, hypothesis 2 is accepted. The second estimate was made with the organizational capital, and the results are shown in Table 3.

\begin{tabular}{|l|r|r|}
\hline \multicolumn{1}{|c|}{ Dependent variable } & EEPC Model \\
\hline Financial Performance & Coefficient & $\begin{array}{r}\text { Standard } \\
\text { Error }\end{array}$ \\
\hline $\begin{array}{l}\text { Machinery and } \\
\text { production equipment }\end{array}$ & $3.6265 *$ & .6179 \\
\hline Property & -.3681 & .4625 \\
\hline $\begin{array}{l}\text { Transportation } \\
\text { Equipment Units }\end{array}$ & .3415 & .4904 \\
\hline Constant & $5.74 *$ & 1.65 \\
\hline R- square & 0.9317 & \\
\hline Observations & 64 & \\
\hline Chi-square & 0.0000 & \\
\hline $\begin{array}{l}\text { Note: * significant at 1\%; } \\
\text { significant at 10\%. }\end{array}$ & \\
\hline
\end{tabular}

Table 3 EEPC model of organizational capital and financial performance

Source: self made

The results expose a significant and positive relationship between machinery, production equipment and financial performance. This is explained because the installed capacity to produce or serve (Gosende, 2016), in the specific case of tourism performance, positively influences finances. It does not happen in the same way with the variables of real estate or with the transport units, which are not related to the dependent. This partially assumes hypothesis 3. The third estimate was made with technological capital and the results are shown in Table 4.

\begin{tabular}{|l|l|l|}
\hline \multicolumn{1}{|c|}{ Dependent variable } & \multicolumn{2}{c|}{ EEPC Model } \\
\hline Financial Performance & Coefficient & $\begin{array}{l}\text { Standard } \\
\text { Error }\end{array}$ \\
\hline Office team & -18.6213 & 6.3712 \\
\hline Peripheral components & 50.9787 & 16.8793 \\
\hline Constant & 1.97 & 5.63 \\
\hline R-square & 0.0619 & \\
\hline Observations & 64 & \\
\hline Chi-square & 0.0098 & \\
\hline $\begin{array}{l}\text { Note: } * \text { significant at } 1 \% ; * \\
\text { significant at } 10 \% .\end{array}$ \\
\hline
\end{tabular}

Table 4 EEPC model of technological capital and financial performance

Source: self made
This capital showed significant relationships between peripheral components, office equipment and financial performance. The peripheral components have a significant and positive relationship, which is explained because any accessory or equipment linked to the PC, generates greater financial performance. For example, scanners, printers, monitors, USB's, wireless chargers, mouse, keyboard, headphones, bluetooth, among other devices, are examples of this.

In the case of office equipment, the relationship is significant, but negative. This is explained because real estate is not significant in productivity, because digital businesses allow the reduction of operating costs, the efficiency of the processes and therefore the financial performance. Companies like Amazon, Airbnb, Uber, among others, do not need office equipment to develop their operations. The development of applications and software management allows these digital companies to reduce costs, be efficient and increase their financial performance. With this, hypothesis 4 is accepted.

\section{Conclusions}

In recent decades, most companies have sought to identify and measure these assets, classifying them into different types of intellectual capital. However, the investigation of this capital has received little attention from academics. Due to this growing interest in the digital economy and knowledge management in the tourism industry, this research was oriented to the study of intangible assets in the tourism sector.

The analysis of the intellectual capital and the elements that integrate it, are projected as an exploration field for researchers and businessmen, since the results presented here show a significant relationship between this capital and the performance of companies, as was the case with The restaurant industry in Mexico.

This article contributes to generate empirical evidence in the analysis of intellectual capital on business performance, the results of this research partially support the fact that IC is an important strategic asset for financial performance. 
The empirical results support hypotheses 2 and 4 on human and technological capital, respectively, only by verifying partial relations between organizational capital and financial performance. In this way, the human-technology interaction is evidenced as a sustainable competitive advantage for small and medium enterprises in the tourism sector in Mexico.

It is important to highlight that this research, particularly at the country level, did not seek to generalize the results obtained here, however, they can be considered as the basis for future research on the measurement of financial performance in the tourism industry.

From a business perspective, tourism managers are recommended to look at the analysis of intellectual capital and its influence on financial performance. Regarding the educational perspective, it is suggested that higher education institutions strengthen their training processes for the tourism industry with the purpose of increasing their presence and competitiveness in said industry, ensuring that human capital acquires the intangible elements demanded by this sector. Likewise, it is beneficial to address the human factor as an important element of the competitiveness of the tourism industry.

\section{References}

Amiri, N., Shirkavand, S., C halak, M., \& Rezaeei, N. (2017). Competitive Intelligence and Developing Sustainable Competitive Advantage. Ad-Minister, (30): 173-194. doi:https://doi.org/10.17230/ad-minister.30.9

Antoni, M., Maug, E., \& Obernberger, S. (2019). Private equity and human capital risk. Journal of Financial Economics, 133(3): 634-657. doi:https://doi.org/10.1016/j.jfineco.2019.04.01 0

Argilés-Bosch, J., García-Blandón, J., Ravenda, D., Valencia-Silva, M., \& Somoza, A. (2017). The influence of the trade-off between profitability and future increases in sales on cost stickiness. Estudios de Economia, 44(1): 81-104.

Badinger, H., Egger, P., \& von Ehrlich, M. (2019). Productivity Growth, Human Capital and Technology Spillovers: Nonparametric Evidence for EU Regions. Oxford Bulletin, 81(4): 768-779. doi:https://doi.org/10.1111/obes.12285

ISSN: 2414-4835

ECORFAN $^{\circledR}$ Todos los derechos reservados
Benini, R. (2016). Some key policy issues related to technology change, knowledge and absorption capacities in a country comparison perspective. Economic Change \& Restructuring, 49(2/3):

95-112. doi:https://doi.org/10.1007/s10644-016-9189-7

Benítez, R. (2016). BBVA.com. Recuperado de BBVA.com:

https://www.bbva.com/es/machine-learningque-es-y-como-funciona/

Buenechea-Elberdin, M., Sáenz, J., \& Kianto, A. (2018). Knowledge management strategies, intellectual capital, and innovation performance: a comparison between high- and low-tech firms. Journal of Knowledge Management, 22(8): 1757-1781. doi:https://doi.org/10.1108/JKM04-2017-0150

Carnes, C., Xu, K., Sirmon, D., \& Karadag, R. (2019). How Competitive Action Mediates the Resource Slack-Performance Relationship: A Meta-Analytic Approach. Journal of Management Studies, 56(1): 57-90. doi:https://doi.org/10.1111/joms.12391

Dinh, T., Kang, H., Morris, R., \& Schultze, W. (2018). Evolution of intangible asset accounting: Evidence from Australia. Journal of International Financial Management \& Accounting, $\quad 29(3): \quad$ 247-279. doi:https://doi.org/10.1111/jifm.12081

Felli, L., \& Harris, C. (2018). Firm-specific training. Journal of Economic Theory, 175: 585623.

doi:https://doi.org/10.1016/j.jet.2018.01.010

Garanina, T., \& Dumay, J. (2018). Forwardlooking intellectual capital disclosure in IPOs. Journal of Intellectual Capital, 18(1): 128-148. doi:https://doi.org/10.1108/JIC-05-2016-0054

Garechana, G., Rio-Belver, R., Zarrabeitia, E., \& Alvarez-Meaza, I. (2019). From Research to Industry: A Quantitative and Qualitative Analysis of Science-Technology Transferences and Emergence Patterns in Bioremediation. IEEE Transactions on Engineering Management, $1-12$. doi:10.1109/TEM.2019.2936364
PÉREZ-CRUZ, Omar Alejandro, NANDE-VÁZQUEZ, Edgard Alfredo and MARTÍNEZ-VERDUGO, Juan Carlos. The economic policy cycle and public debt in México. A retrospective analysis of 2012-2016 period. Journal of Social Researches. 2020 
Ginesti, G., Caldarelli, A., \& Zampella, A. (2018). Exploring the impact of intellectual capital on company reputation and performance. Journal of Intellectual Capital, 19(5): 915-934. doi:https://doi.org/10.1108/JIC-01-2018-0012

Gosende, P. (2016). Evaluación de la distribución espacial de plantas industriales mediante un índice de desempeño. Revista de administração de emprêsas, 56(5): 533-546. doi:10.1590/S0034-759020160507

Hye-Young, J. (2018). Examining the effects of government intervention on the firm's environmental and technological innovation capabilities and export performance. International Journal of Production Research, 56(18): 6090-6111. doi:10.1080/00207543.2018.1430902

Jung, J., \& López-Baso, E. (2017). Factor accumulation, externalities, and absorptive capacity in regional growth: evidence from Europe. Journal of Regional Science, 57(2): 266-289. doi:https://doi.org/10.1111/jors.12304 Kmieciak, R. (2019). Improving SME performance through organizational memory. Journal of Organizational Change Management, $\quad 32(4)$ : 473-491. doi:https://doi.org/10.1108/JOCM-01-20190003

Kogan, L., Papanikolaou, D., Seru, A., \& Stoffman, N. (2017). Technological Innovation, Resource Allocation, and Growth. Quarterly Journal of Economics, 132(2): 665-712. doi:https://doi.org/10.1093/qje/qjw040

Kum-Sik, O., \& Anchor, J. (2017). Factors affecting reverse knowledge transfer from subsidiaries to multinational companies: Focusing on the transference of local market information. Canadian Journal of Administrative Sciences, 34(4): 329-342. doi:https://doi.org/10.1002/cjas.1440

Lee, K., Kim, Y., \& Joshi, K. (2017). Organizational memory and new product development performance: Investigating the role of organizational ambidexterity. Technological Forecasting and Social Change, 120: 117-129. doi:https://doi.org/10.1016/j.techfore.2016.12.0 16
Liu, C., Chang, A., \& Fang, Y. (2019). Network activities as critical sources of creating capability and competitive advantage. Management Decision, 57(8): 1729-1733. doi:https://doi.org/10.1108/MD-08-2017-0733

Ma, Z., Zhu, J., Meng, J., \& Teng, J. (2019). The impact of overseas human capital and social ties on Chinese returnee entrepreneurs' venture performance. International Journal of Entrepreneurial Behavior \& Research, 25(1): 67-83. doi:https://doi.org/10.1108/IJEBR-072017-0246

Manju, T., Kashiramka, S., \& Jain, P. (2018). Flexibility in Measuring Corporate Financial Performance, EVA Versus Conventional Earnings Measures: Evidences from India and China. Global Journal of Flexible Systems Management, $\quad$ 19(2): 123-138. doi:https://doi.org/10.1007/s40171-017-0178-0

Osei, H., Agyapong, A., \& Owusu Kwateng, K. (2019). The moderated mediation processes in firm-specific human capital development and task performance relationship. International Journal of Organizational Analysis,, 27(3): 396413. doi:https://doi.org/10.1108/IJOA-11-20171274

Overstreet , R., Skipper, J., Huscroft, J., Cherry, M., \& Cooper, A. (2019). Multi-study analysis of learning culture, human capital and operational performance in supply chain management. Journal of Defense Analytics and Logistics, $\quad 3(1)$ : 41-59. doi:https://doi.org/10.1108/JDAL-11-20180017

Papageorgiadis , N., Xu, Y., \& Alexiou, C. (2019). The Effect of European Intellectual Property Institutions on Chinese Outward Foreign Direct Investment. Management and Organization Review, 15(1): 81-110. doi:https://doi.org/10.1017/mor.2018.38

Pelinescu, E. (2015). The Impact of Human Capital on Economic Growth. Procedia Economics and Finance, 22: 184-190. doi:https://doi.org/10.1016/S22125671(15)00258-0

Pérez, O., \& Barragán, C. (2018). La innovación y el rendimiento financiero en la industria turística: un estudio empírico en México. Fórum Empresarial, 23(1): 59-74. doi:https://doi.org/10.33801/fe.v23i1.15700 
Prawitz, D., \& Cohart, J. (2016). Financial Management Competency, Financial Resources, Locus of Control, and Financial Wellness. Journal of Financial Counseling \& Planning, 27(2):

142-157.

doi:https://doi.org/10.1891/1052-3073.27.2.142

Rivera, L., Rivera, J., \& Reducindo, I. (2016). Desarrollo de cursos de educación a distancia: una experiencia entre la UASLP y el INEGI. Apertura, Revista de Innovación Educativa, 8(1): 1-17.

Sardo, F., \& Serrasqueiro, Z. (2018). Intellectual capital, growth opportunities, and financial performance in European firms. Journal of Intellectual Capital, 19(4): 747-767. doi:https://doi.org/10.1108/JIC-07-2017-0099

Sharabati, A., Nour, A., Shamari, N., Durra, A., \& Moghrabi, K. (2016). The Impact of Intellectual Capital on Business Performance in Kuwaiti Telecommunication Industry. International Journal of Business Performance Management, $\quad$ 17(4): $\quad 428-\quad 446$. doi:10.1504/IJBPM.2016.079278

Shou, Y., Prester, J., \& Li, Y. (2018). The Impact of Intellectual Capital on Supply Chain Collaboration and Business Performance. IEEE Transactions on Engineering Management, 2: 113. doi:10.1109/TEM.2018.2870490

Stucki, T., \& Wochner, D. (2018). Technological and organizational capital: Where complementarities exist. Journal of Economics \& Management Strategy, 28(3): 458-487. doi:https://doi.org/10.1111/jems.12269

Sun, Q., \& Xiolan, M. (2019). Financing intangible capital. Journal of Financial Economics, $\quad$ 133(3): $\quad 564-588$ doi:https://doi.org/10.1016/j.jfineco.2019.04.00 3

Tovar, J., \& Tavares, J. (2015). Trade, scale or social capital? Technological progress in poor and rich countries. Journal of International Trade \& Economic Development, 24(6): 767808.

doi:https://doi.org/10.1080/09638199.2014.969

757
Villasalero, M. (2014). University knowledge, open innovation and technological capital in Spanish science parks. Journal of Intellectual Capital, 15(4): 479-496. doi:https://doi.org/10.1108/JIC-07-2014-0083

Wag, Y., Su, X., Wang, H., \& Zou, R. (2019). Intellectual capital and technological dynamic capability: evidence from Chinese enterprises. Journal of Intellectual Capital, 20(4): 453-471. doi:https://doi.org/10.1108/JIC-06-2018-0096

Werr, A., \& Runsten, P. (2013). Understanding the role of representation in interorganizational knowledge integration. The Learning Organization, $\quad 20(2)$ : 118-133. doi:https://doi.org/10.1108/0969647131130376 4

Wood, S., Coe, N., \& Wrigley, N. (2016). MultiScalar Localization and Capability Transference: Exploring Embeddedness in the Asian Retail Expansion of Tesco. Regional Studies, $\quad 50(3)$ : $\quad 475-495$. doi:https://doi.org/10.1080/00343404.2014.926 317

Xu, J., \& Li, J. (2019). The impact of intellectual capital on SMEs' performance in China. Journal of Intellectual Capital, 20(4): 488-509. doi:https://doi.org/10.1108/JIC-04-2018-0074 